\title{
The Magnesium and other Inorganic Constituents of some Marine Invertebrates.
}

By

\author{
R. A. McCance and H. L. Shipp, \\ Biochemical Laboratory, King's College Hospital, London.
}

With 1 Figure in the Text.

THE livers of some of the marine invertebrates are well known to contain unusually high concentrations of certain of the heavy metals, such as iron, which are normally found in smaller amounts throughout the animal kingdom. Other invertebrate animals contain relatively high concentrations of metals which are not usually found, or only in the merest traces, in the higher animals. The present paper describes what is believed to be a new observation not quite falling into either category.

In the course of some work on the organic and inorganic constituents of food the following marine invertebrates were subjected to analysis: Oysters (Ostrea edulis), Scallops (Pecten maximus), Winkles (Littorina littorea), Mussels (Mytilus edulis), and Whelks (Buccinum undatum). These were all analysed cooked, except the Mussels and Oysters, and nothing very striking was observed in their inorganic 'make up' except in the case of the Winkles and the Whelks. These animals were found to contain 414 and $16 \theta \mathrm{mg}$. of magnesium respectively per $100 \mathrm{~g}$. of wet cooked flesh. These figures are the mean of several analyses. In mammals, birds and fish the magnesium was found to lie between 10 and $35 \mathrm{mg}$. per $100 \mathrm{~g}$. of live weight and to vary to some extent with the organ. Muscular tissue, for example, contained 22 to $35 \mathrm{mg}$. per $100 \mathrm{~g}$. and mammalian kidney $16 \mathrm{mg}$. per $100 \mathrm{~g}$., while eggs and fish roes (male and female) contained only $10 \mathrm{mg}$. per $100 \mathrm{~g}$. The $\frac{\mathrm{Na}}{\mathrm{Mg}}$ ratios in fish and mammalian muscle lay between $\frac{3}{1}$ and $\frac{5 \cdot 5}{1}$.

The detection of these abnormal magnesium concentrations in the winkles and the whelks was considered of sufficient biological interest to warrant further investigation. With the assistance of the Director and Members of the Marine Biological Association's Laboratory at Plymouth, Cardium edule, Pecten maximus, and Littorina littorea were obtained in 
the raw state and the individual organs analysed. Water, sodium, potassium, calcium, magnesium and iron were determined. A complete survey of the methods used is in course of publication. (McCance \& Shipp, 1933.) A brief note on the magnesium technique is, however, necessary. After incineration of the material and extraction with hydrochloric acid the solution was neutralised to phenol red, made just acid with acetic acid and the calcium removed as the oxalate. The magnesium was precipitated from the calcium free solution as magnesium ammonium phosphate, and the phosphate in the precipitate determined by Brigg's (1922) method.

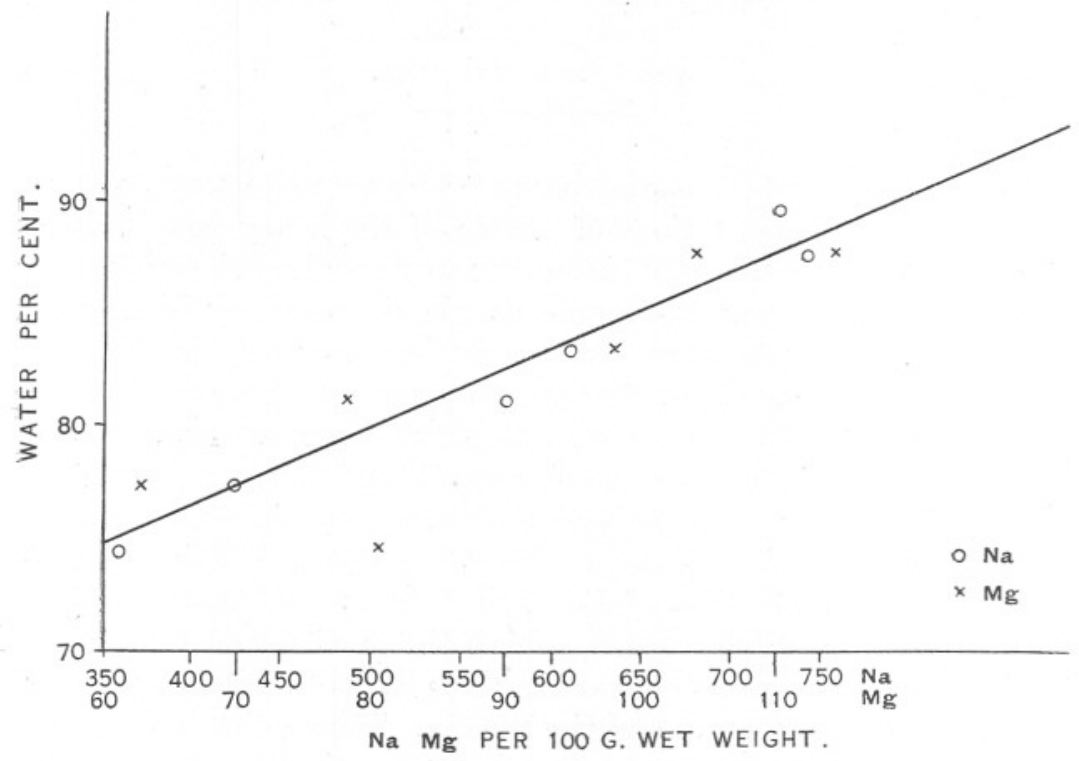

Fig. 1.-The relation between the water and the sodium-magnesi um contents of the organs of Pecten maximus.

To ensure that the whole of the phosphate was present as the magnesium salt and not in combination with some quite unexpected metal, a large amount of the precipitate from the winkles was collected and weighed after ignition to the pyrophosphate. The weight of phosphate in the ignited salt corresponded with the theoretical amount required for magnesium pyrophosphate, and no metal other than magnesium was found when the precipitate was dissolved and subjected to qualitative analysis.

The results obtained may be found in Table I (p. 296).

The points to which we wish to draw attention are :-

(1) The very high concentration of magnesium in Littorina littorea. The $\frac{\mathrm{Na}}{\mathrm{Mg}}$ ratio in these animals is approximately $\frac{1}{1}$. The element appears to 
be distributed throughout all the organs in amounts which would be fatal to higher animals. The physiological significance of this is at present quite obscure.

(2) The high but rather variable magnesium in the different organs of Cardium and Pecten. In Pecten $\frac{\mathrm{Na}}{\mathrm{Mg}}$ is roughly $\frac{6 \cdot 5}{1}$ and in Cardium $\frac{4 \cdot 3}{1}$. It will be observed that the magnesium, sodium and water tend to vary together. The relationship in Pecten is demonstrated by Figure 1 .

(3) The low concentration of magnesium in mussels and oysters. The $\frac{\mathrm{Na}}{\mathrm{Mg}}$ ratios are about $\frac{14}{1}$.

(4) The potassium concentration in the various organs of these invertebrates runs parallel not with the water but with the dry matter. The potassium, as might have been expected, seems to form an integral part of the protoplasm and only small variations are compatible with life.

(5) The variations in iron from one animal to another and from one organ to another are striking and their importance unknown.

\section{SUMMARY.}

The sodium, potassium, calcium, magnesium and iron of a number of marine invertebrates have been determined and some of the findings are very briefly discussed.

The common winkle Littorina littorea contains $330-510 \mathrm{mg}$. of magnesium per $100 \mathrm{~g}$. of live weight. All the organs appear to contain these high concentrations. Boiled specimens of whelks contained about $160 \mathrm{mg}$. of magnesium per $100 \mathrm{~g}$.

We should like to thank the Director and Staft of the Laboratory of the Marine Biological Association for their assistance. R. A. McC. has held a part-time grant and H. L. S. a full time grant from the Medical Research Council during this work.

\section{REFERENCES.}

BRIGGs, A. P. 1922. A modification of the Bell-Doisy phosphate method. Journal Biol. Chemistry, Vol. 53, p. 13.

McCance, R. A., and Shipp, H. L. 1933. Medical Research Council Special Report Series (in press). 


\section{TABLE I}

\begin{tabular}{|c|c|c|c|c|c|c|c|}
\hline Animal. & Organ. & $\begin{array}{c}\text { Water } \\
\%\end{array}$ & \multicolumn{5}{|c|}{$\begin{array}{l}\text { Na. } \quad \mathrm{K} . \mathrm{Ca} . \mathrm{Mg} . \quad \mathrm{Fe} \text {. } \\
\text { mg. per } 100 \mathrm{~g} \text {. of live wet weight. }\end{array}$} \\
\hline Mytilus edulis & Whole & & 290 & 315 & 90 & 23 & $5 \cdot 8$ \\
\hline strea edulis & Whole & & 650 & 258 & 185 & 41 & \\
\hline Littorina littorea & Foot & $64 \cdot 6$ & 425 & 375 & 265 & 346 & $17 \cdot 8$ \\
\hline & Mantle & $70 \cdot 9$ & 415 & 277 & 1266 & 334 & $18 \cdot 7$ \\
\hline & Gonad & $65 \cdot 2$ & 342 & 390 & 168 & 460 & \\
\hline & Stomach and Liver & $67 \cdot 7$ & 438 & 473 & 550 & 507 & 33 . \\
\hline Pecten maximus & Foot & $83 \cdot 6$ & 612 & 250 & 42 & 97 & \\
\hline & Mantle & $87 \cdot 9$ & 742 & 148 & 52 & 104 & \\
\hline & & 77 & 424 & 38 & 26 & 63 & \\
\hline & Gonad & $81 \cdot 1$ & 566 & 28 & 38 & 78 & \\
\hline & Gills & 89 & 726 & 143 & 54 & 111 & \\
\hline & Stomach & $74 \cdot 4$ & 351 & 262 & 118 & 80 & 11 \\
\hline Cardium edule & Foot & $77 \cdot 4$ & 510 & 305 & 41 & 93 & 15 \\
\hline & Mantle & $84 \cdot 5$ & 61 & 18 & 180 & 117 & \\
\hline & Muscle & $73 \cdot 5$ & 482 & 30 & 70 & 84 & \\
\hline & Gills & $83 \cdot 5$ & 294 & 239 & 87 & 106 & \\
\hline & Stomach, Liver, etc. & $71 \cdot 1$ & 241 & 302 & 145 & 94 & \\
\hline
\end{tabular}

